\title{
A systematic review of the effectiveness of interventions to reduce motor vehicle crashes and their injuries among the general and working populations
}

\author{
Álvaro Lefio, ${ }^{1}$ Vivienne C. Bachelet, ${ }^{2}$ Rosa Jiménez-Paneque, ${ }^{3}$ Patricio Gomolán ${ }^{3}$ \\ and Katherinne Rivas ${ }^{1}$
}

Suggested citation

Lefio A, Bachelet VC, Jiménez-Paneque R, Gomolán P, Rivas K. A systematic review of the effectiveness of interventions to reduce motor vehicle crashes and their injuries among the general and working populations. Rev Panam Salud Publica. 2018;42:e60. https://doi.org/10.26633/RPSP.2018.60

Keywords
Objective. To summarize the best available international scientific evidence on the effectiveness of interventions to reduce motor vehicle collisions and their consequences among the working and general populations.

Methods. A broad and systematic review was conducted of the literature available in biomedical databases and grey literature. At least two investigators working in parallel performed data extraction, synthesis, and risk of bias analysis.

Results. Forty-one studies with low to moderate risk of bias were included. Of these, 18 had an ecological design (time series), 10 were quasi-experimental, one was a population survey, one was a randomized clinical trial, and 11 were systematic reviews.

Conclusions. The interventions that most consistently show a positive effect on incidence, morbidity, and mortality due to motor vehicle collisions are national policies or programs that: regulate, enforce, and penalize driving under the influence of alcohol; improve driving safety and driver conditions; improve road infrastructure with the purpose of preventing collisions; and educate and penalize drivers with a history of road violations.

Accidents, traffic; accidents, occupational; occupational mortality; occupational injuries; driving under the influence.
In 2013, motor vehicle collisions were the leading cause of death among the population 15 - 29 years of age, killing 1.25 million individuals globally (1). While there has been a worldwide tendency towards stabilization of deaths from road crashes, significant inequity

Escuela de Salud Pública, Universidad de Chile, Santiago, Chile. Send correspondence to Vivienne C. Bachelet, vivienne.bachelet@usach.cl

2 Facultad de Ciencias Médicas, Universidad de Santiago de Chile, Santiago, Chile.

Medwave Estudios Limitada, Santiago, Chile. between high-income countries and low- and middle-income countries persists (1). From an occupational viewpoint, vehicle crashes are one of the most frequent types of work trajectory accidents and pose the greatest risk of death and disability, especially for workers with jobs related to driving or transportation (2). From the perspective of economic costs, the burden of road collisions is very significant, estimated at $2 \%$ of the gross domestic product in the United States of America (3), and at $1.5 \%-3.9 \%$ in countries of Latin America (4).

Observational studies have pinpointed a variety of risk factors for this public health problem, some of which are: being male, having low income, having a low education level, poor road infrastructure, safety conditions related to vehicles, careless driving, driving under the influence of alcohol or other drugs, and deficient accident emergency-response (5-7). In addition, there are specific work-related risk factors, such as fatigue due to long 
driver shifts, driver workload leading to tension, lack of driver training, and other factors that reflect organizational safety policy and culture (8).

The World Health Organization (WHO) has been monitoring the global scope of this health problem and has proposed several important public policies to address it. Several countries have implemented these measures, to varying degrees. The countries with the worst indicators have been slow and superficial in following these policy recommendations (1).

In the context of global concern for the consequences of traffic collisions, the 2015 the United Nations 2030 Agenda for Sustainable Development (9) includes a target of reducing road traffic deaths and injuries by one-half by 2020. To achieve this goal, the United Nations is urging governments to adopt policies and programs geared toward reducing the incidence of traffic fatalities and injuries. This, in turn, creates the need to rigorously and comprehensively analyze interventions in order to further define priorities and guide decisionmaking. Particularly in low- and middle-income countries, where $90 \%$ of crashes occur with more than double the mortality (1), it is especially important that government and business decisionmakers have access to quality information. In other words, understanding the effectiveness of interventions is important at not only the population and national levels, but also in the workplace where interventions target the employee population.

This study aimed to identify, analyze, and synthesize the best available international scientific evidence on the effectiveness of interventions to reduce motor vehicle collisions and their consequences among the general and working populations. It was commissioned by a workers' health and safety organization, Mutual de Seguridad de la Cámara Chilena de la Construcción (Santiago, Chile) to help inform policy decisions on motor vehicle-related deaths and injuries among the working population.

\section{MATERIALS AND METHODS}

\section{Search strategy}

A broad and specialized search was conducted of the main international databases that contain biomedical scientific articles and grey literature: PubMed/
MEDLINE (U.S. National Library of Medicine, Bethesda, Maryland, United States); Cochrane Library (The Cochrane Collaboration, London, United Kingdom); LILACS (Latin American and Caribbean Center on Health Sciences Information, Pan American Health Organization/ WHO, São Paulo, Brazil); EMBASE (Excerpta Medica Database, Elsevier, Amsterdam, the Netherlands); HTA and DARE (Health Technology Assessments and Database of Abstracts of Reviews of Effects, Centre for Reviews and Dissemination, University of York, York, United Kingdom); and Epistemonikos (Epistemonikos Foundation, Santiago, Chile).

The websites of the following sources were also searched: Work Zone Safety Inc. (Crest Hill, Illinois, United States); European Agency for Safety and Health at Work (Bilbao, Spain); International Labor Organization, International Road Traffic and Accident Database (Paris, France); Networks of Employers for Traffic Safety (Vienna, Austria); World Bank (Washington, DC, United States); Instituto Nacional de Seguridad e Higiene en el Trabajo (Madrid, Spain); Inter-American Development Bank (New York, United States); Safe Cube Project (Loughborough, United Kingdom); WHO (Geneva, Switzerland); and the Organization for Economic Cooperation and Development Library (Paris, France).

To improve the search specificity and relevance of the search strategy, the appropriate thesaurus for each database was utilized, such as MeSH (Medical Subject Headings, U.S. National Library of Medicine, Bethesda, Maryland, United States) and DeCS (Health Science Descriptors, Latin American and Caribbean Center on Health Sciences, São Paulo, Brazil). The MeSH descriptors used were: "accidents, traffic;" "public policy;" "accidents, occupational;" "policy;" "programs;" "public sector." The DeCS descriptors were: "accidentes de tránsito;" "política social;" "accidentes de trabajo;" "políticas;" "programas;" "sector público." When no specific or more complex descriptors were available in these thesauruses, synonyms were used to enhance the search, for example: "implementation," "intervention," "worker," "effectiveness," "public intervention," "business," "public program," and "road traffic injuries." The specific search strategies for each source are available from the authors upon request.
Considering the significant amount of information published on the topic, the search was limited to a period of 10 years (January 2006 - October 2016), with the understanding that systematic reviews would cover prior periods, and to papers published in either English or Spanish.

\section{Study selection}

Considering that motor vehicle collisions are a population problem, selection criteria sought to identify studies with a broad array of epidemiological research designs. The inclusion criteria were the following: studies in human beings; original research on interventions with results on outcomes, such as reduced incidence, injuries, and/or mortality from road traffic crashes; and quantitative assessment of results. Also included were: experimental studies (randomized clinical trials, population trials); observational studies (systematic reviews with or without meta-analysis, ecological studies, cohort studies, and case reports); and quasi-experimental studies; as well as systematic reviews, which in accordance with the Cochrane Handbook for Systematic Reviews of Interventions (10), can be considered a specific research design that answers overarching and complex public health questions.

Articles excluded were those that only reported conceptual frameworks, goals, processes, or qualitative assessment of programs and interventions without quantitative analysis of their estimated effect; non-systematic reviews and clinical practice guidelines; articles that reported changes in knowledge, attitudes, or other surrogate variables; market studies, polls, and surveys; and studies with poor methodological quality per the critical analysis criteria of this study.

\section{Data extraction and analysis}

Data and references were extracted and systematized into results tables. Two of the researchers worked in parallel extracting and assessing the methodological quality of the recruited studies. Differences were solved by consensus or were refereed by a third researcher. Studies were categorized into high, medium, and low risk of bias. For quality assessment, a critical analysis tool was created. For randomized controlled trials, this tool was based on the Centre for Evidence Based Medicine of the University 
of Oxford (11); for systematic reviews, on the AMSTAR guidelines (12); and the observational studies, on the STROBE initiative (13). Lastly, for quality assessment of quasi-experimental and ecological studies, a structured guide was created to detect the main risks of bias. The final instrument is available from the authors upon request.

Studies with a high risk of bias were excluded. The results were compiled in tables and in narrative form, and included the type of intervention, research methods, reported outcomes, and effectiveness.

\section{RESULTS}

Initially 66 studies were evaluated. Of those, 41 studies were selected that had a low- or medium-risk of bias and that answered the study question. Of these, 18 had an ecological design (mostly time-series); 10 were quasi-experimental; one was a population survey; one was a randomized clinical trial; and 11 were systematic reviews. Figure 1 shows the PRISMA flow diagram and the reasons for exclusion. A complete list of excluded documents is available from the authors upon request.

The types of interventions that were most frequently assessed included regulatory policies on alcohol consumption; programs or policies designed to enhance driving and driver safety; educational interventions; and programs or interventions on road infrastructure or safety. Less frequently assessed interventions were improvements on vehicle safety, police enforcement, increases in the price of gasoline, and brief interventions on populations with an alcohol consumption problem. An assessment of the impact of tobacco restriction laws was also identified.

Most of the studies focused on the prevention of motor vehicle collisions and their consequences on the general population. Only three studies evaluated workplace interventions, two of which used a quasi-experimental design and one that was an ecological study $(14-16)$. These studies assessed programs based on stringent control of alcohol consumption among drivers (15) and enforcement of safety standards in the United States (14). As shown in Table 1, all three showed a positive effect, but the greatest was specific enforcement of safety measures (14) that resulted in a $19.2 \%$ yearly average reduction in traffic accidents (95\% Confidence Interval [95\%CI]: 13.3 - 25.1).

With regards to interventions to prevent traffic crashes and their consequences among the general population, this review comprises a significant body of evidence that reports a significant positive effect of programs and policies to regulate alcohol consumption. Interventions that stand out in terms of quantity and quality of evidence were: raising alcohol taxes $(17,18)$; reducing permissible alcohol blood levels in drivers (17, 19 - 23); blocking automatic car ignition with a blood-alcohol level sensor in previously penalized drivers $(19,24)$; restricting alcohol sales to under-age persons (22); police enforcement with inhaled alcohol tests $(22,25,26)$; and a set of laws called "zero tolerance" that consist of a series of regulations to restrict alcohol consumption in drivers

FIGURE 1. PRISMA a flow diagram for search and exclusions in a systematic review of the effectiveness of interventions to reduce motor vehicle crashes and their injuries among the general and working populations, January 2006 - October 2016

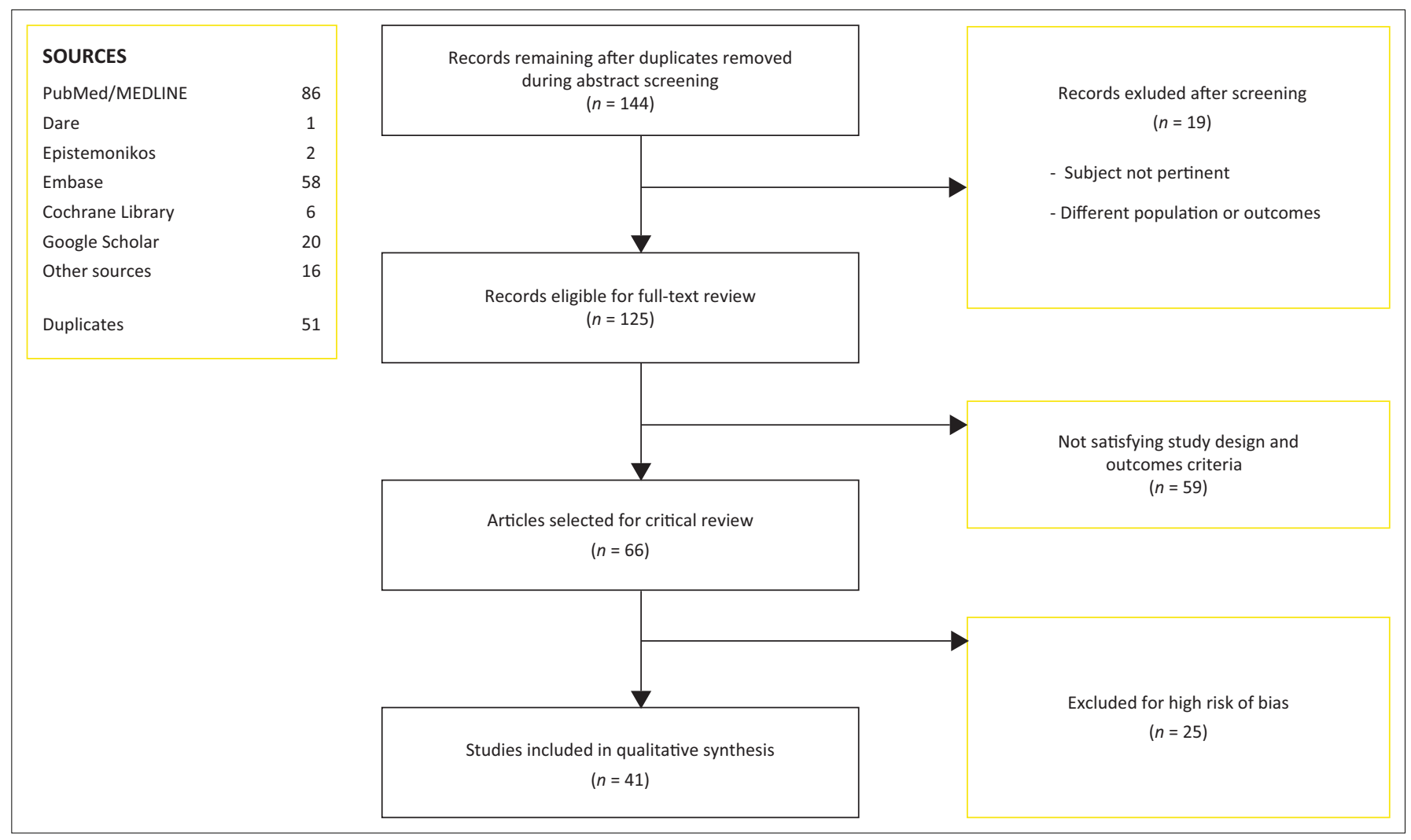

a Preferred Reporting Items for Systematic Reviews and Meta-Analyses.

Source: Prepared by the authors from the study results. 
TABLE 1. Brief description of studies on work place interventions to reduce traffic accidents among the working population, January 2006 - October 2016

\begin{tabular}{|c|c|c|c|c|c|}
\hline Study & Study design & Intervention & Results & Risk of bias & Effect \\
\hline Chen, 2008 & Quasi-experimental & $\begin{array}{l}\text { A United States federal program monitoring } \\
\text { motor carrier safety and regulatory } \\
\text { compliance of trucking companies using a } \\
\text { Compliance Review (CR). }\end{array}$ & $\begin{array}{l}\text { Among those who had CR, the number of } \\
\text { crashes increased on average } 19.2 \% \\
\text { annually in the years before the CR year } \\
\text { (95\% Confidence Interval [95\% } 1 \text { CI]: } 13.3- \\
25.1 \text { ) and decreased on average } 27.2 \% \text { in } \\
\text { the CR year ( } 95 \% \mathrm{Cl}: 20.5-33.9) \text {. }\end{array}$ & Medium & Positive \\
\hline Brady, 2009 & Quasi-experimental & $\begin{array}{l}\text { A mandatory alcohol-testing program to } \\
\text { reduce alcohol involvement in motor carrier } \\
\text { crashes, including pre-employment testing; } \\
\text { random testing before, during and after } \\
\text { driving shift; and post-accident testing. } \\
\text { Drivers with a blood alcohol concentration of } \\
0.02-0.03 \mathrm{~g} / \mathrm{dL} \text { are removed from duty for } 24 \\
\text { hours. In the case of accident, drivers are } \\
\text { tested within } 2 \text { hours. }\end{array}$ & $\begin{array}{l}\text { The odds of alcohol involvement after } \\
\text { implementation of the program was } \\
\text { reduced by } 48 \% \text { for motor carrier drivers } \\
\text { (adjusted odds ratio [aOR] }=0.52 ; 95 \% \mathrm{Cl} \text { : } \\
0.43-0.64 \text { ) and by } 32 \% \text { for other drivers } \\
\text { (aOR=0.68; } 95 \% \mathrm{Cl}: 0.65 \text { to } 0.71 \text { ). }\end{array}$ & Medium & Positive \\
\hline Marlenga, 2006 & Ecological & $\begin{array}{l}\text { Law-mandated tractor certification course for } \\
\text { youth operators. }\end{array}$ & $\begin{array}{l}\text { No statistically significant reduction in } \\
\text { crashes after enactment. }\end{array}$ & Medium & No effect \\
\hline
\end{tabular}

Source: Prepared by the authors from the study results.

and to increase penalties for driving under the influence $(17,20,27)$. One of these studies showed that a $1 \%$ increase in beer taxes resulted in a $0.37 \%$ decrease in alcohol-related traffic fatalities per 100000 population (17). Likewise, heightened police enforcement through publicized sobriety checkpoint programs (26) resulted in a $14.0 \%-16.7 \%$ reduction of fatal crashes $(P<0.05)$. On the other hand, it has been shown in the United States that lowering the legally allowable blood-alcohol concentration for drivers reduced the incidence of fatal crashes (21), such that a $0.01 \mathrm{~g} / \mathrm{dL}$ change in the limit resulted in an increase of 0.228 times in the rate of monthly deaths per state $(P<0.05)$. In contrast, a study showed that lifting the Sunday ban on alcohol sales is associated with increased motor vehicle crashes (33), a finding that was also corroborated in New Mexico (29), but not in Japan (30).

Educational interventions have not been shown to be effective in reducing traffic accidents or ensuing injuries, neither those designed for at-risk populations, such as young drivers or cyclists, nor those carried out in high-alcohol consumption settings $(31-33)$.

Another group of interventions with a significant number of good quality studies is comprised of driver and driving safety programs and policies. These interventions share a common focus on risky driving behaviors, together with driver capacity and training. This review found the most effective interventions were mandatory seat belts $(33-36)$, antilock brake systems (37), camera speed control $(38-40)$, helmet use by motorcycle drivers (36), and graduated driver licensing for new drivers $(27,41-44)$. Several studies assessed graduated driver licensing in the United States, both federally and in states, and showed that implementation of this program reduced accidents in young, inexperienced drivers by $19 \%-39 \%(27)$.

Road safety programs associated with infrastructure projects, such as street and intersection lighting (27), public works and road investment in black spots or areas with a high number of traffic incidents (45), and dedicated streetcar rights-of-way (46) have proven effective in reducing motor vehicle crashes. Interventions that target black spots (45) have resulted in an estimated $15 \%$ reduction in urban and rural crashes $(P<0.001), 29 \%$ reduction of accidents in roundabouts, $19 \%$ for traffic island on approach, $59 \%$ for bike lanes, and $52 \%$ for ban on right turns $(P<0.001)$.

Increasing the price of gasoline has also been shown to be effective in reducing road accident rates. A study found that a $10 \%$ increase in gasoline prices was associated with a $2.0 \%$ decrease in monthly crashes among male drivers and $2.1 \%$ among female drivers (47).

Table 2 summarizes the interventions and their estimated effects. The complete table with the detailed descriptions and analysis of the included studies for the general population is available as Supplementary Material.

\section{DISCUSSION}

The results of this review show that among the general population, the interventions that most consistently decrease road crash incidence, injuries, and fatal outcomes are policies or programs to:

- Regulate, enforce, and penalize driving under the influence of alcohol, such as limiting blood-alcohol concentration, police sobriety checkpoints, raising alcohol taxes, ignition blocking for penalized drivers, and restricting alcohol sales to under-age people.

- Enhance safety driving and driver standards, such as graduated driver licensing, mandatory seatbelts, camera speed control, and bicycle and motorcycle helmets.

- Improve road infrastructure to prevent crashes, such as street and crossroads lighting and structural changes to areas with high risk of crashes.

- Educate and penalize drivers with a history of traffic accidents and misbehavior.

Among the working population, interventions most frequently shown to be effective are enforcement of national safety standards in the workplace (for companies that have transport operations) and interventions that use mandatory testing to prevent and severely restrict alcohol consumption.

Our review of the literature also confirms the importance of speeding and alcohol consumption as part of the multiple causes of motor-vehicle crashes. 
TABLE 2. Summary of interventions to reduce motor vehicle crashes and related injuries among the general and working populations, by category, description, and estimated effect, January 2006 - October 2016

\begin{tabular}{|c|c|c|}
\hline Intervention category & Description & Effect \\
\hline \multirow[t]{3}{*}{ Educational intervention } & Educational programs geared to bicyclists & No effect \\
\hline & Educational interventional on alcohol-consuming settings & No effect \\
\hline & School-based educational intervention on young drivers & No effect \\
\hline \multirow[t]{10}{*}{ Policies or programs that regulate alcohol consumption } & Increasing taxes and restricting sales on certain days & Positive \\
\hline & Reducing limits on blood alcohol concentration and increasing penalties & Positive \\
\hline & Ignition blocking on convicted drivers & Positive \\
\hline & Alcohol product and sales deregulation & No effect \\
\hline & Lifting Sunday bans to alcohol sales & Negative \\
\hline & Brief intervention on alcohol consumption for persons involved in car accidents & No effect \\
\hline & Alcohol sales restricted for minors & Positive \\
\hline & Suspending license of convicted drivers & Positive \\
\hline & Police enforcement with alcohol breath test & Positive \\
\hline & Zero tolerance laws & Positive \\
\hline \multirow[t]{3}{*}{ Policies or programs on driver, passenger, and driving safety } & Mandatory use of seatbelts & Positive \\
\hline & Graduated driver licensing & Positive \\
\hline & Speed camera controls & Positive \\
\hline \multirow[t]{4}{*}{ Programs that enhance road safety and infrastructure } & Crossing guards & No effect \\
\hline & Interventions and infrastructure investment on high-risk road intersections (hot spots) & Positive \\
\hline & Street lighting & Positive \\
\hline & Streetcar right-of-way & Positive \\
\hline \multirow[t]{3}{*}{ Company and workplace interventions } & Programs that enforce safety measures in transportation companies & Positive \\
\hline & Alcohol control program with mandatory checks for motor-vehicle drivers & Positive \\
\hline & Educational intervention and certification of tractor drivers & No effect \\
\hline Interventions on vehicle safety & Antilock brake system & Positive \\
\hline Interventions that target problem drivers & Educational and punitive programs for problem drivers & Positive \\
\hline Economic policies & Increasing the price of gasoline & Positive \\
\hline Other types of interventions & Tobacco control policies & No effect \\
\hline
\end{tabular}

Source: Prepared by the authors from the study results.

We found that there is a need to restrict and regulate these behaviors in drivers, based on enforcing existing regulations.

On the other hand, this review found that implementation of educational measures and communications campaigns on a stand-alone basis are not effective in reducing public health indicators related to motor vehicle collisions, except in the case of graduated driver licensing that target inexperienced drivers. They aim to promote technical competencies in driving motorized vehicles, have a duration of several years, and its beneficiaries are young populations that are more receptive to behavioral changes.

Limitations. This study had three limitations worth considering. First, the search was restricted to articles in English or Spanish, thereby excluding studies in other languages. Second, most studies on this topic were either quasi-experimental or ecological. Though based on real-world interventions, which have inherent pragmatic value, these studies are more prone to bias and have limited capacity for explaining causality. Lastly, the study was affected by a gap in the research-studies that evaluate interventions for occupation-related motor vehicle injury and fatality are lacking. This is an important shortcoming, particularly because occupational health authorities specifically commissioned this review. This gap limits options for decisionmakers charged with recommending and implementing policies specifically geared to work-related hazards.

\section{Conclusions}

In conclusion, this review provides an overview on the effectiveness of programs and policies that aim to reduce injuries and deaths from motor crashes. These interventions regulate and enforce measures regarding driving under the influence of alcohol; educate and train young drivers through graduated licensing programs; mandate the use of seatbelts and motorcycle helmets; use cameras to limit speeding; implement road infrastructure improvements; and educate and restrict drivers with a history of traffic violations.

The results of this review are consistent with most of the WHO recommendations on road crash prevention. The findings also contribute quality information to aid decisionmakers striving to reduce the social consequences and burden of motor-vehicle collisions and to prioritize policy and enforcement measures based on the best available scientific evidence. Our review also warns policymakers not to overrate standalone educational and communications campaigns, as they have not demonstrated a significant impact. Such campaigns have not proven their worth as of yet, and can instead detract from proven, effective measures. 
Finally, one of the least studied areas is the effectiveness of interventions geared toward preventing road crashes among the working population. More studies are needed on the specifics of workplace hazards and interventions to reduce work-related road crashes and collisions. Additional research on these avoidable injuries and fatalities would provide a broader basis for evidence-informed policy on occupational health and safety.
Acknowledgements. The authors wish to thank the Comunidad de Práctica para la Gestión de la Prevención de Accidentes de Tránsito (Task Force on Traffic Accident Prevention) and the Applied Research Department, both of the Mutual de Seguridad de la Cámara Chilena de la Construcción (Santiago, Chile) for input and feedback while conducting this review.

Funding. This review was funded by Mutual de Seguridad de la Cámara Chilena

\section{REFERENCES}

1. World Health Organization. Global status report on road safety 2015. Geneva: WHO; 2015.

2. Boufous S, Williamson A. Work-related traffic crashes: a record linkage study. Accid Anal Prev. 2006;38(1):14-21.

3. Albalate D, Fernández L, Yarygina A. The road against fatalities: infrastructure spending vs. regulation? Accid Anal Prev. 2013;59:227-39.

4. Bhalla K, Diez-Roux E, Taddia AP, De la Peña Mendoza SM, Pereyra A. The costs of road injuries in Latin America 2013. New York: Inter-American Development Bank; 2013.

5. Museru L, Mcharo CN, Leshabari MT. Road traffic accidents in Tanzania: a ten year epidemiological appraisal. East Cent African J Surg. 2002;7(1):23-6.

6. Kanchan T, Kulkarni V, Bakkannavar SM, Kumar N, Unnikrishnan B. Analysis of fatal road traffic accidents in a coastal township of South India. J Forensic Leg Med. 2012;19(8):448-51.

7. Shrivastava SR, Shrivastava PS, Ramasamy J. Scope of public health measures in ensuring road safety. J Inj Violence Res. 2014;6(2):95-6.

8. Messier S, Bellavance F, Duguay P. Les accidents routiers au travail: une revue de littérature. Canadá: Institut de Recherche Robert-Sauvé en Santé et en Sécurité du Travail; 2013.

9. United Nations. Transforming our world: the 2030 Agenda for Sustainable Development. 2015. Available from: https://sustainabledevelopment.un.org/ post2015/transformingourworld Accessed 3 October 2016.

10. Higgins JPT, Green S, eds. Cochrane Handbook for Systematic Reviews of Interventions Version 5.1.0. The Cochrane Collaboration; 2011. Available from http:/ / handbook-5-1.cochrane.org/ Accessed 6 September 2016.

11. Center For Evidence Based Medicine. Critical appraisal tools. UK: Oxford University. Available from: http://www. cebm.net/critical-appraisal Accessed 1 September 2016.

12. Shea BJ, Grimshaw JM, Wells GA, Boers $\mathrm{M}$, Andersson N, Hamel C, et al. Development of AMSTAR: a measurement tool to assess the methodological quality of systematic reviews. BMC Med Res Methodol. 2007;7:10.

13. White RG, Hakim AJ, Salganik MJ, Spiller MW, Johnston LG, Kerr L, etal. Strengthening the Reporting of Observational Studies in Epidemiology for respondent-driven sampling studies: "STROBE-RDS" statement. J Clin Epidemiol. 2015;68(12):1463-71.

14. Chen GX. Impact of federal compliance reviews of trucking companies in reducing highway truck crashes. Accid Anal Prev. 2008;40(1):238-45.

15. Brady JE, Baker SP, Dimaggio C, McCarthy ML, Rebok GW, Li G. Effectiveness of mandatory alcohol testing programs in reducing alcohol involvement in fatal motor carrier crashes. Am J Epidemiol. 2009; 170(6):775-82.

16. Marlenga B, Doty BC, Berg RL, Linneman JG. Evaluation of a policy to reduce youth tractor crashes on public roads. Inj Prev. 2006;12(1):46-51.

17. Chang K, Wu C-C, Ying Y-H. The effectiveness of alcohol control policies on alcohol-related traffic fatalities in the United

18. Elder RW, Lawrence B, Ferguson A, Naimi TS, Brewer RD, Chattopadhyay SK, et al. The effectiveness of tax policy interventions for reducing excessive alcohol consumption and related harms. Am J Prev Med. 2010;38(2):217-29.

19. Killoran A, Canning U, Doyle N, Sheppard LU. Review of effectiveness of laws limiting blood alcohol concentration levels to reduce alcohol-related road injuries and deaths. London: National Institute for Health and Clinical Excellence; 2010.

20. Nagata T, Hemenway D, Perry MJ. The effectiveness of a new law to reduce alcohol-impaired driving in Japan. JMAJ. 2006;4911(12):365-9.

21. Wagenaar AC, Maldonado-Molina MM, Ma L, Tobler AL, Komro KA. Effects of legal BAC limits on fatal crash involvement: analyses of 28 states from 1976 through 2002. J Safety Res. 2007;38(5):493-9.

22. Fell JC, Scherer M, Thomas S, Voas RB. Effectiveness of social host and fake identification laws on reducing underage drinking driver fatal crashes. Traffic Inj Prev. 2014;15(suppl 1):S64-73.

23. Staton C, Vissoci J, Gong E, Toomey N, Wafula R, Abdelgadir J, et al. Road traffic States. Accid Anal Prev. 2012;45:406-15. de la Construcción. The funders had no role in study design, data collection or analysis, decision to publish, or preparation of the manuscript.

\section{Conflict of interests: None declared.}

Disclaimer. Authors hold sole responsibility for the views expressed in the manuscript, which may not necessarily reflect the opinion or policy of the RPSP/ PAJPH and/or PAHO. injury prevention initiatives: a systematic review and metasummary of effectiveness in low and middle income countries. PLoS One. 2016;11(1):e0144971.

24. Kaufman EJ, Wiebe DJ. Impact of state ignition interlock laws on alcohol-involved crash deaths in the United States. Am J Public Health. 2016;106(5):865-71.

25. Jones L, Hughes K, Atkinson AM, Bellis MA. Reducing harm in drinking environments: a systematic review of effective approaches. Health Place. 2011;17(2):508-18.

26. Bergen G, Pitan A, Qu S, Shults RA, Chattopadhyay SK, Elder RW, et al. Publicized sobriety checkpoint programs: a community guide systematic review. Am J Prev Med. 2014;46(5):529-39.

27. Thompson NJ, McGee RE, Feng J. Impact of Georgia's teenage and adult driver responsibility act: 15-year follow-up. Traffic Inj Prev. 2016;17(2):195-201.

28. Middleton JC, Hahn RA, Kuzara JL, Elder $\mathrm{R}$, Brewer R, Chattopadhyay $\mathrm{S}$, et al. Effectiveness of policies maintaining or restricting days of alcohol sales on excessive alcohol consumption and related harms. Am J Prev Med. 2010;39(6):575-89.

29. McMillan GP, Lapham S. Effectiveness of bans and laws in reducing traffic deaths: legalized Sunday packaged alcohol sales and alcohol-related traffic crashes and crash fatalities in New Mexico. Am J Public Health. 2006;96(11):1944-8.

30. Desapriya E, Fujiwara T, Dutt N, Arason N, Pike I. Impact of the 1994 alcohol production and sales deregulation policy on traffic crashes and fatalities in Japan. AsiaPacific J Public Heal. 2012;24(5):776-85.

31. Ker K, Chinnock P. Interventions in the alcohol server setting for preventing injuries. Cochrane Database Syst Rev. 2008; (3):CD005244

32. Ian $R$, Irene $K$, Cochrane Injuries Group Driver Education Reviewers. School based driver education for the prevention of traffic crashes. Cochrane Database Syst Rev. 2001;(3):CD003201.

33. Bacchieri G, Barros AJD, Santos JV dos, Gonçalves H, Gigante DP. A community intervention to prevent traffic accidents among bicycle commuters. Rev Saude Publica. 2010;44(5):867-75.

34. Soori H, Nasermoadeli A, Ainy E, Hassani SA, Mehmandar MR. Association between 
mandatory seatbelt laws and road traffic injuries in Iran. Southeast Asian J Trop Med Public Health. 2011;42(6):1540-5.

35. Costich JF, Slavova SS. Using enforcement and adjudication data to assess the impact of a primary safety belt law. Traffic Inj Prev. 2015;16(7):664-8.

36. Abegaz T, Berhane Y, Worku A, Assrat A. Effectiveness of an improved road safety policy in Ethiopia: an interrupted time series study. BMC Public Health. 2014;14(1):539.

37. Khorasani-Zavareh D, Shoar S, Saadat S. Antilock braking system effectiveness in prevention of road traffic crashes in Iran. BMC public health. 2013;13:439.

38. Blais E, Carnis L. Improving the safety effect of speed camera programs through innovations: evidence from the French experience. J Safety Res. 2015;55:135-45.

39. Pérez K, Marí-Dell'Olmo M, Tobias A, Borrell C. Reducing road trafficinjuries: effectiveness of speed cameras in an urban setting. Am J Public Health. 2007;97(9):1632-7.
40. Llau FA, Ahmed NU, Khan HMRU, Cevallos FG, Pekovic V. The impact of red light cameras on crashes within MiamiDade County, Florida. Traffic Inj Prev. 2015;16(8):773-80.

41. Porchia BR, Baldasseroni A, Dellisanti C, Lorini C, Bonaccorsi G. Effectiveness of two interventions in preventing traffic accidents: a systematic review. Ann Ig. 2014;26(1):63-75.

42. Ehsani JP, Bingham CR, Shope JT. Graduated driver licensing for new drivers: effects of three states' policies on crash rates among teenagers. Am J Prev Med. 2013;45(1):9-18.

43. Chen Y, Berrocal VJ, Bingham CR, Song PXK. Analysis of spatial variations in the effectiveness of graduated driver's licensing (GDL) program in the state of Michigan. Spat Spatiotemporal Epidemiol. 2014;8:11-22.

44. Males M. California's Graduated Driver License Law: effects on older teenagers. Californian J Health Promot. 2006;4(3): 207-21.
45. Meuleners LB, Hendrie D, Lee AH, Legge M. Effectiveness of the black spot programs in Western Australia. Accid Anal Prev. 2008;40(3):1211-6.

46. Richmond SA, Rothman L, Buliung R, Schwartz N, Larsen K, Howard A. Exploring the impact of a dedicated streetcar right-of-way on pedestrian motor vehicle collisions: a quasi experimental design. Accid Anal Prev. 2014;71: 222-7.

47. Chi G, McClure TE, Brown DB. Gasoline prices and traffic crashes in Alabama, 19992009. Traffic Inj Prev. 2012;13(5):476-84.

Manuscript received on 4 August 2017. Accepted for publication on 11 December 2017.
Revisión sistemática de la efectividad de las intervenciones para reducir las colisiones de vehículos de motor y lesiones Asociados Resultantes en la población general y la población económicamente activa

Palabras clave motor y sus consecuencias en la población general y la población económicamente activa.

Métodos. Revisión amplia y sistemática de la bibliografía contenida en las bases de datos biomédicas y la literatura gris. Al menos dos investigadores trabajando en paralelo realizaron la extracción de datos, la síntesis y el análisis del riesgo de sesgo.

Resultados. Se incluyeron 41 estudios con un riesgo de sesgo bajo o moderado. De ellos, 18 tenían un diseño ecológico (series de tiempo), 10 eran cuasiexperimentales, 1 era una encuesta poblacional, 1 era un ensayo clínico aleatorizado y 11 eran revisiones sistemáticas.

Conclusiones. Las intervenciones que muestran más sistemáticamente un efecto positivo sobre la incidencia, la morbilidad y la mortalidad por colisiones de vehículos de motor son las políticas o programas nacionales que reglamentan, hacen cumplir los reglamentos y sancionan a quienes conducen bajo los efectos del alcohol; mejoran la seguridad al conducir y con respecto a los conductores; mejoran la infraestructura vial a fin de prevenir las colisiones; y educan y sancionan a los conductores con antecedentes de infracciones de las leyes de tránsito.

Accidentes de tránsito; mortalidad laboral; accidentes de trabajo; traumatismos ocupacionales; bajo la influencia. 
RESUMO Objetivo. Sintetizar as melhores evidências científicas internacionais disponíveis sobre a efetividade das intervenções para reduzir os acidentes de trânsito e suas consequências na população geral e na população ativa.

Revisão sistemática da Métodos. Foi realizada uma ampla revisão sistemática da literatura em bases de efetividade de intervenções para reduzir os acidentes de trânsito e ferimentos na população geral e na população ativa dados biomédicas e da literatura cinzenta. A extração e a síntese dos dados e a análise de risco de viés foram conduzidas em paralelo por, pelo menos, dois pesquisadores.

Resultados. Foram selecionados para análise 41 estudos com risco de viés baixo a moderado. Destes, 18 possuíam design ecológico (série temporal), 10 eram estudos quase-experimentais, um estudo era um levantamento populacional, um era um estudo clínico randomizado e 11 eram revisões sistemáticas.

Conclusões. As intervenções que sistematicamente demonstraram um efeito positivo na incidência, morbidade e mortalidade de acidentes de trânsito são as políticas ou programas nacionais para regulamentar, cumprir as leis e aplicar sanções aos condutores que dirigem sob influência de álcool, melhorar a segurança e condições para condução de veículos, melhorar a infraestrutura viária visando evitar acidentes e educar e multar os condutores com histórico de infrações.

Palavras-chave Acidentes de trânsito; mortalidade ocupacional; acidentes de trabalho; traumatismos ocupacionais; dirigir sob a influência. 